\title{
Atomic Simulation on Fracture of Metals at High Temperatures
}

by

\section{Takayuki KITAMURA*}

Key words : Atomic simulation, Fracture, High temperature, Grain boundary, Surface, Cavity, Grain boundary groove, Diffusion, Stress

\section{1 はじめに}

破壞現象を原子的視点より説明しようとする試みはか なり以前よりなされていた. しかし, その基礎的な取組 みの重要性が認識され, 本格的な解明への模索が開始さ れたのはごく最近のことである．昨今，破壊に関する原 子レベルの研究が注目されている理由として, (1) 超大 規模集積回路やマイクロマシンのように非常に微小な要 素からなる機器の開発がますます進み, それらの要素で は原子オーダーの局部的な破損が機器全体の信頼性に直 結すること，(2) 従来材料の破壊研究の進展のみならず, 新素材の特性発現研究の要望にともなって, 材料の破壊 機構をミクロな素過程に遡って理解することがますます 必要となってきたこと,（3）複合材料に代表される新材 料では, 材料全体の強度が界面等の局所における破壊特 性に強く依存すること等があげられる。一方, 研究手段 の側面からは，新たな原理に基づく顕微鏡の開発や計算 機能力の飛躍的向上に伴って原子レベルからの実験観察 や数值解析が可能になってきたことが，この分野の発展 の原動力となりつつある. とりわけ, 数值解析は, 実験 が極めて困難である条件（例えば，高温，高圧，高速） 下の現象や直接観察が不可能な材料内部の状況について もシミュレーションできるため, 局所破壊の過程をつぶ さに解明する手段として大きな期待が寄せられている.

さて，高温においては原子の動きが活発であり，粒界 や界面等の不安定な局所部分の原子が移動して部材全体 の破壊の原因となる欠陥が形成される場合がある。この ような局所部分の特性評価には, 原子シミュレーション が大きな威力を発揮する，ただし，現時点においては， 破壊過程に関する本格的な原子レベルからの検討が開始 されたばかりであり，体系的に整理されているわけでは ない，また，通常の構造物におけるバルク材料の大規模 な破壊を直接シミュレーションできるものでもない．本 稿では，原子シミュレーションによって高温破壊現象を 理解しようとする研究動向の一端を紹介して, 今後の方 向性を探る端緒としたい。

\section{2 粒界特性の数值シミュレーション}

まず，高温破壊の起点となる粒界に着目して，局所不
安定性について原子シミュレーションによって検討され た結果について述べる.

\section{$2 \cdot 1$ 分子動力学法とメトロポリス法}

原子の挙動を数值シミュレーションによって解析する 代表的方法として, 分子動力学法とメトロポリス法があ る.

\section{分子動力学法は，各原子に対して運動方程式

$$
\vec{F}_{i}=m_{i} \vec{a}_{i}
$$

を作成し，それを差分法で解くことによって各原子の運 動を時間を追って逐一シミュレーションする方法である。 ここで, $m_{i}$ と $\vec{a}_{i}$ は原子 $i$ の質量および加速度, $\vec{F}_{i}$ は 原子 $i$ に働く力である. 一般に, $\vec{F}_{i}$ はその瞬間の原子 配置によって決定されるポテンシャルエネルギーの原子 間距離に対する微分として求められる．すなわち，ある 時間における原子配置より式(1)を用いて $\vec{a}_{i}$ が求められ る.これと各原子の運動量を組合わせると，差分法によ り一瞬後の各原子の位置および運動量を決定することが できる，これを繰返すと各原子について，各原子の位置 および速度の変化を時間を追って求めることができる. 分子動力学法は動的現象の過程を解析することができる ため，破壊過程を原子レベルでシミュレーションするに は適切な手段である。ただし，計算に膨大な時間を要す るので, 大領域・長時間の解析はできないのが欠点であ る.

一方，メトロポリス法は確率的に原子の安定配置を求 める方法であり，モンテカルロ法と称されることが多い 従来より計算機によって発生させた乱数を用いて確率的 シミュレーションを行う方法をモンテカルロ法と称して おり，紛らわしいため本論文ではメトロポリス法とする。 具体的には，適当な初期原子配置より以下の手順によっ て原子を動かして，平衡状態の原子配置を求める.

（1）任意の原子を抽出し，任意の方向へ微小距離だけ 変位させる。

(2) 変位により系のポテンシャルエネルギが減少する 場合には，変位した原子配置を受入れる。

(3) 変位により系のポテンシャルエネルギが $\Delta \Phi$ 増 加する場合には, $\exp (-\Delta \Phi / k T)$ の確率で変位し

$†$ 原稿受理 平成 6 年 5 月 18日 Received May 18, 1994

* 正会員 京都大学大学院工学研究科機械物理工学専攻 ₹606-01 京都市左京区吉田本町, Div. of Eng. Physics \& Mech., Kyoto Univ., Sakyoku, Kyoto 606-01 
た原子配置を受入れる.ここで， $k$ はボルツマン定 数， $T$ は温度である。

（4）変位が受入れられなかった場合には，元の原子位 置に戻す。

（5）（1)〜(4)を繰返す.

メトロポリス法では原子の運動の経過を追跡できない が，効率的に原子の安定配置を求めることができ，かつ, プログラムが容易である．したがって，粒界エネルギー や表面エネルギーおよびそれらの構造解析には分子動力 学法よりも優れている. なお, 平衡状態に関する分子動 力学法の結果はメトロポリス法のそれと一致する.

\section{$2 \cdot 2$ 粒界エネルギー}

原子シミュレーションが最も多く適用されている課題 のひとつが, 粒界エネルギーや粒界構造に関する解析で ある゙．図1(a), (b) は，それぞれ fcc 金属（金および銅） および bcc 金属（モリブデンおよび鉄）の [110] tilt boundaryに対して, 傾角 $\psi$ を変化させて粒界エネルギ 一を計算した結果である. ここで，金とモリブデンには 多体ポテンシャルの一種である原子埋込み法ポテンシャ ル (Embedded Atom Method), 銅と鉄には LennardJones 型と Johnson 型の二体間ポテンシャルを用いてい る. fcc および bcc のおのおの 2 種の材料は類似した 変化を示しており, 局部的にエネルギーが低くなってい る谷間は規則性が良い対応粒界と一致している. 規則性 の良い粒界は安定であり, 銅で実験的に求められている 傾向と対応している. 後述のように, 粒界やその会合部 が局所破壊の起点になることを考慮すると, 各粒界につ
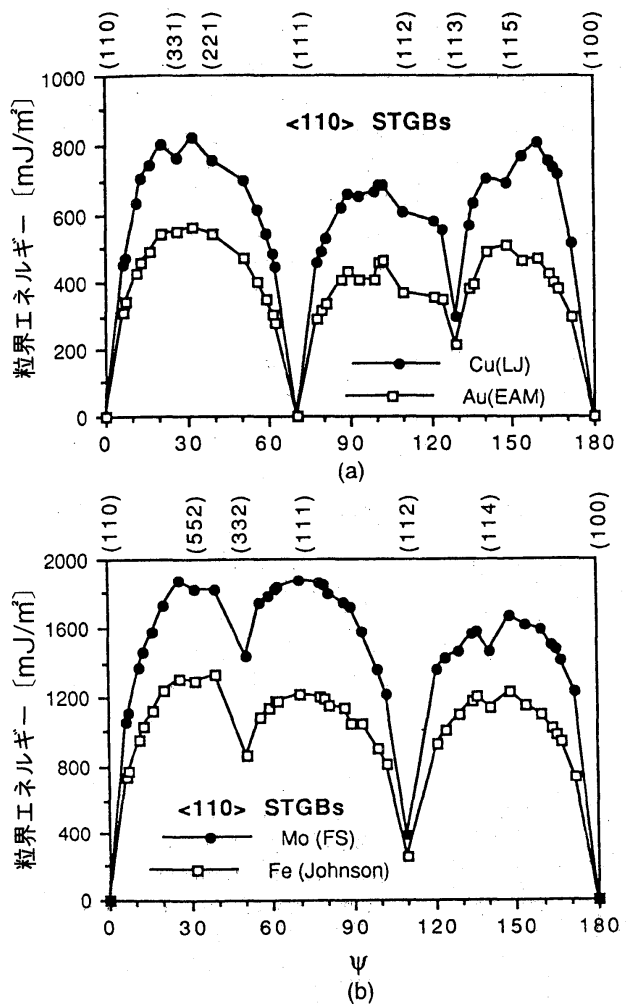

(a) 金と銅の粒界エネルギー

(b) モリブデンと鉄の粒界エネルギー

図 1 粒界エネルギーの傾角依存性 ([110] tilt boundary) ${ }^{9)}$

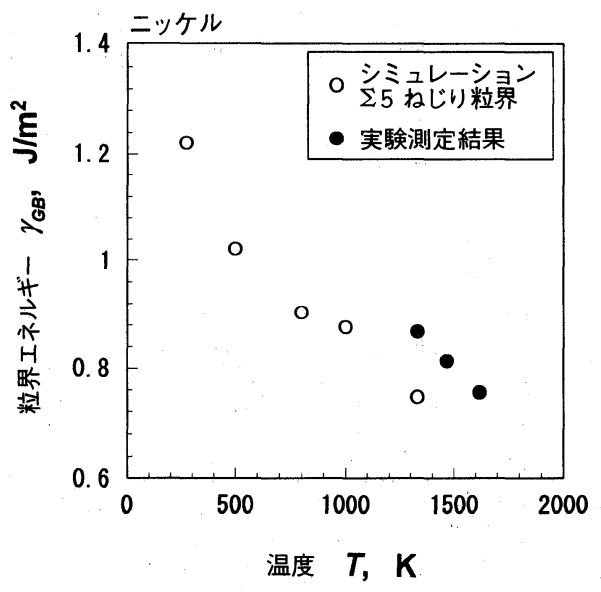

図 2 ニッケルの粒界エネルギーの温度依存性 ${ }^{11)}$. 計算は [100] $\sum 5$ twist boundary に対するもの であり，実験測定 ${ }^{12)} に$ におる粒界は特定されて いない

いて固有の粒界エネルギーを求める必要がある.しかし， 実験的手法には多大な労力を要するため, 各粒界に対し てそれを逐一求めるのは現実的ではない，計算機シミュ レーションを用いれば任意の粒界のエネルギーを簡単に 求めることができ，その場合の粒界極近傍の原子配置よ り粒界構造の詳細を直接知ることができることが大きな 利点である。

図 2 は, 原子埋込み法ポテンシャルを用いてニッケル [100] $\sum 5$ twist boundary について粒界エネルギーの温 度依存性について検討した結果である。図中には実験よ り求められたニッケルの粒界エネルギー（ただし，粒界 は特定されていない）の温度依存性を合わせて示した。 温度が高くなるとともに粒界エネルギーは減少し，高温 において得られている実験測定結果と傾向的に一致して いる。 ここで，計算值がやや低いのは計算対象の粒界の 粒界の規則性が高いためと考えられる．実験手法上の制 約から温度が低くなると粒界エネルギーの実験的評価は 難しくなるが, 計算機シミュレーションではそれらの制 約も克服することができる.

なお，粒界と同様に表面についても数値解析が行われ ている.

\section{$2 \cdot 3$ 粒界や表面の会合部分の安定性}

単結晶で作成した超大規模集積回路上のアルミニウム 配線（線幅約 $1 \mu \mathrm{m}$ ）を高温の放置した際，図 3 に示す ように角部に欠損が生じたことが報告されている。これ は，角部の原子が不安定であり，表面エネルギーの低い 安定な (111) の表面を形成するように移動したためであ

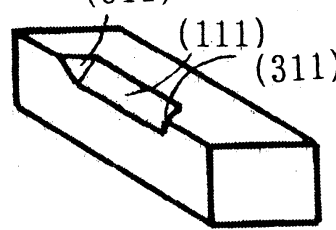

図 3 高温において単結晶アルミニウム配線角部に 発生した欠損の模式図 ${ }^{15)}$. 図中の数字は表面 のミラー指数を示す 


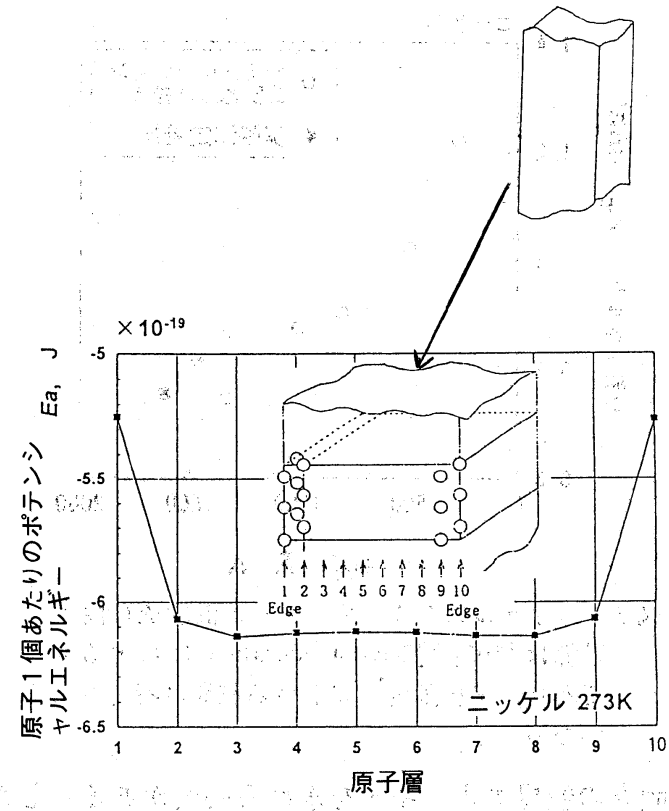

図4 正方形断面を有する二ッケル単結晶極細線 （軸方向は [100]）に扔ける表面（(001）面） 上のポテンシャル分布 ${ }^{16)}$

る. 寸なわち, 局所的に不安定な部分が欠陥の起点とな ることを示唆している：図 4 は, 原子埋込み法ポテン
シャルを用いて求められたニッケル単結晶角断面極細線 の $273 \mathrm{~K}$ における表面（(001）面）原子位置でのポテン シャルエネルギーを計算した例である. 角部のエネルギ 一が高く，不安定であることがわかる.

図 5 は，[100] $\sum 5$ twist boundary を有するニッケル 双結晶極細線の粒界上の原子位置の時間变化を分子動力 学法により求めた結果である。図は粒界面で展開したも のであり，0，A，B 点が $0^{\prime}, \mathrm{A}^{\prime}, \mathrm{B}^{\prime}$ 点に接している。 上 図は粒界を下方から見た図であり，表面は(430) 面と (340) 面である。下図は粒界を上方から見た図であり， 表面は (010)面と (001) 面である。273K の解析であるが, 緩和に伴って $2 つ の$ 表面と粒界が交わる角部の原子の移 動が認められる。特に， $0^{\prime}$ 点では $500 \mathrm{fs}\left(500 \times 10^{-15} \mathrm{~s}\right.$ $=0.5 \mathrm{ps})$ に掠いて印で示した原子が粒界上面より 下面に移行して久損が生じている，すなわち，粒界や表 面が集まる部分が特に不安定であることを示している. 事実，細線では粒界や表面が会合する部分において欠陥 が形成されやすいことが報告されている。また，図より 表面エネルギーが高い粒界下側の表面（(340) 面と (430) 面)では，原子配置が大きく乱れることもわかる。

図 6 は, 図 5 と同じ粒界を有する角断面極細線に刉張 ひずみを負荷した場合の粒界上の原子配置の変化を示す,

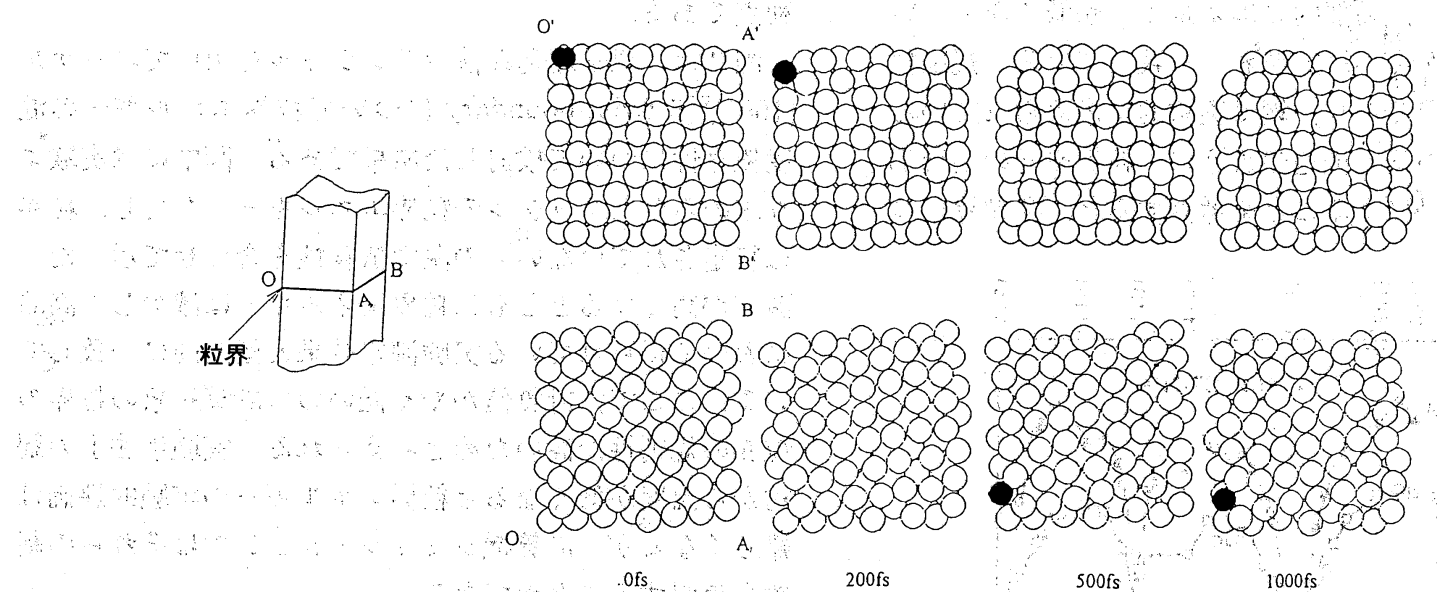

図 5 正方形断面を有する二ッケル双結晶極細線の粒界上の原子配置変化 ${ }^{16)}$. 稙界は

[100] $\sum 5$ twist boündary であり，図は粒界面で極細線を展開して示している
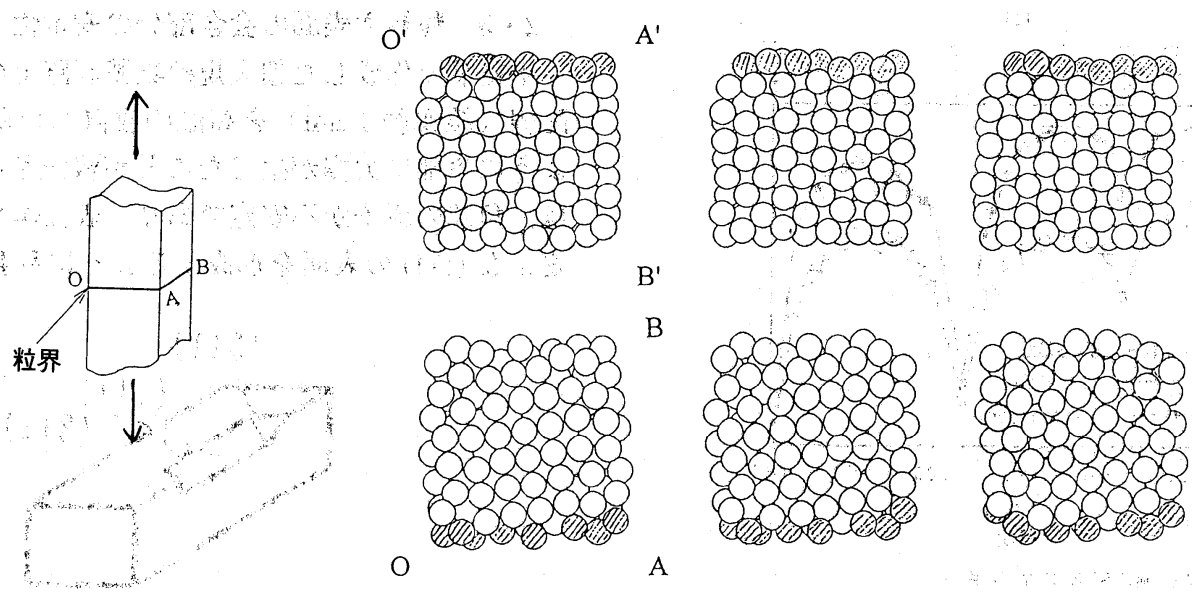

$\mathrm{B}^{\prime}$
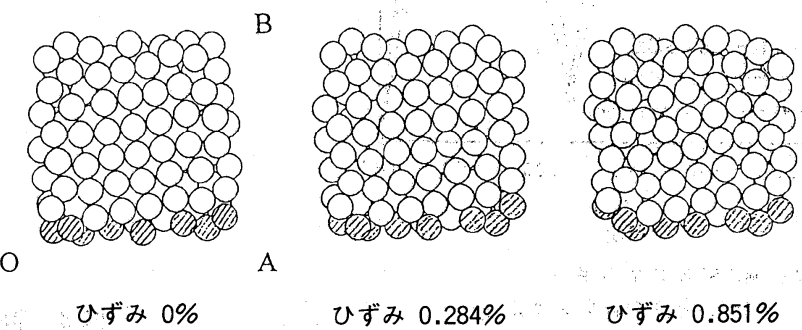

図6 図 5 の二ッケル双結晶極細線（粒界は [100] $\sum 5$ twist boundary）に引張りびずみを負荷した 場合の粒界面上の原子配置 (緩和後 $)^{16)}$. 図は粒界面で極細線を展開して示している 
粒界下面ではひずみ負荷とともに表面原子の乱れが大き くなっている，0点においては下面にも欠損が生じて， 上面（ $0^{\prime}$ 点）とあわせて表面と粒界の会合部分に欠陥 が形成されている，これらは，引張ひずみによって不安 定性がさらに助長されていることを示している。一方, 粒界より上側ではひずみの負荷に対する変化は小さく， 表面（(100) 面と (010)面）の乱れも小さい. すなわち, 表面エネルギーの高い側の表面と粒界の会合部分に原子 配置の大きな乱れが発生し，その角部が原子オーダーの 欠陥の起点となりやすいことを示している.

このような解析を行うことにようて，複数の粒界（界 面）や表面が会合する部分の複雑な負荷条件（多軸, 繰 返し負荷，温度等）における安定性を知ることができる が，体系的に調べられていないのが現状である。

\section{$2 \cdot 4$ 粒界拡散}

高温では活発な原子運動により，粒界や表面に沿って 原子が移動しやすくなる (高速拡散路), これによる集 団的な原子移動が，クリープ変形をもたらしたりキキャ ビティや粒界溝等の欠陷成長を支配することがある。

Kwok らは，分子動力学法によって鉄（Johnson 型ポテ ンシャル）の $\sum 5$ tilt boundary 近傍（図 7) に打りる 原子空孔の動きについて基礎的な検討を行うとともに, 空孔のジャンプの様相を詳細に観察している。表 I (a) は，解析の結果を整理したものであって，Nはシミュ レーション中に観察されたジャンプ数である. 特に，温 度 $1300 \mathrm{~K}$ - $1500 \mathrm{~K}$ において 100 を越えるジャンプが観 察されている. 表 I (b) は, $1300 \mathrm{~K}$ において観察された 空孔のジャンプ前後の位置によって分類し，遷移確率と して表した結果である. 空孔は，粒界面の極近傍のB の位置を伝って粒界に沿いながら移動することがわかる. このように，原子シミュレーションにより粒界拡散を確 率的なミク口挙動より明らかにすることができる.

この他の高温における粒界特性として，粒界近傍の空

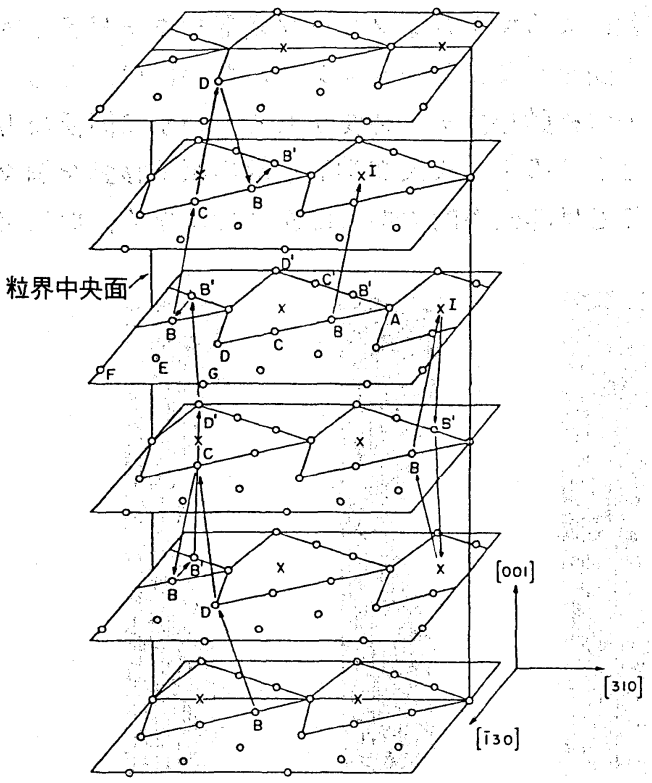

図 7 鉄の $\sum 5$ tilt boundary の原子配置 ${ }^{19)}$. 粒界は 各原子層のメ印を結ぶように各層に垂直に存 在している
表 I 鉄の $\Sigma 5$ tilt boundary の自己粒界拡散に 関するシミュレーション結果 ${ }^{19)}$

(a) 温度, シミュレーション時間扔 よび観察された空孔のジャンプ数

\begin{tabular}{r|r|r}
\hline$T(\mathrm{~K})$ & $T$ (psec) & $N$ (jumps) \\
\hline 900 & 20 & 2 \\
1100 & 40 & 2 \\
1300 & 390 & 193 \\
1400 & 390 & 264 \\
1500 & 390 & 353 \\
1600 & 190 & \\
1700 & 10 & \\
1800 & 90 & \\
1900 & 10 & \\
2100 & 5 & \\
\hline
\end{tabular}

(b) $1300 \mathrm{~K}$ のミュレーションより得られた空孔のジャンプに 関する遷移確率. $\mathrm{A} \sim \mathrm{G}$ は図 7 の粒界近傍の原子位置を示す

\begin{tabular}{l|l|l|l|l|l|l|l}
\hline & A & B & C & D & E & F & G \\
\hline A & 0.0 & 0.005 & 0.010 & 0.0 & 0.0 & 0.0 & 0.0 \\
B & 0.0 & 0.485 & 0.052 & 0.108 & 0.0 & 0.0 & 0.0 \\
C & 0.015 & 0.072 & 0.0 & 0.010 & 0.005 & 0.0 & 0.0 \\
D & 0.0 & 0.082 & 0.031 & 0.0 & 0.026 & 0.026 & 0.0 \\
E & 0.0 & 0.0 & 0.010 & 0.021 & 0.0 & 0.0 & 0.005 \\
F & 0.0 & 0.0 & 0.0 & 0.026 & 0.005 & 0.0 & 0.0 \\
G & 0.0 & 0.0 & 0.0 & 0.0 & 0.0 & 0.005 & 0.0 \\
\hline
\end{tabular}

孔の移動に及ぼす粒界の影響, 粒界移動や粒界すべり, 粒界の溶融等を原子シミェレーションによって基礎的に 解明しようとする努力がなされている.

\section{3. 欠陥初期生成の数值シミュレーション}

高温では，熱活性化された原子の移動に伴って粒界上 にナノからマイクロメートル・オーダのクリープキャビ ティ等の欠陥が生成される。この非平衡な欠陥形成過程 を分子動力学によってシミュレーションすることは原理 的には可能である. しかし, 分子動力学では全原子の原 子振動まで詳細にシミュレーションするため, シミュレ ーション時間・領域が非常に限定される。したがって, 欠陥形成過程を詳細にシミュレーションすることは非効 率であるばかりでなく，多くのケースでは計算機の能力 から不可能である. 多少の計算機能力の向上ではこの困 難を克服できないため, 原子的視点からの簡単化シミュ レーション法が必要となる。このような要求に適合する シミュレーション手段としては, 原子オーダのモンテカ ルロシミュレーションがあげ゙られる。これは，計算機に よって発生させた乱数を用いて，過程を支配する適切な 確率に従って原子を移動させるシミュレーション法であ る。ただし，破壊過程のシミュレーションに用いられた 例は少ない.

図 8 に模式的に示すように，原子移動に伴うポテン シャルエネルギの変化が一方向に傾斜している場合には, 原子が隣接格子位置との間の鞍部におけるポテンシャル の高さが左右方向によって異なる。原子は鞍部のポテン シャルの低い方（図では右方）へ移動しやすく，原子の 移動に方向性が生じる，すなわち，基本的に原子の移動 は系全体のポテンシャルエネルギが減少する方向に生じ る.このような原子移動によって，原子が集団で特定の 


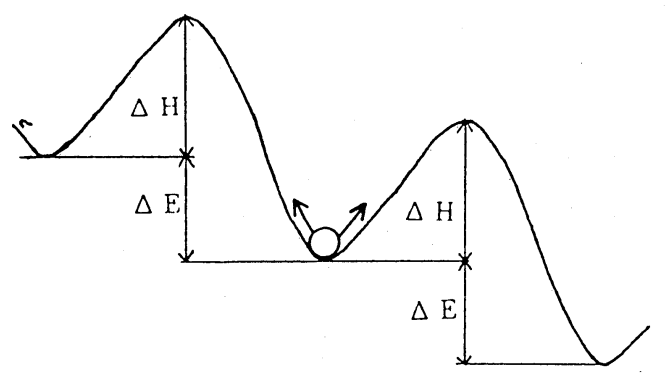

図 8 ジャンプ原子のポテンシャルエネルギー変化の 模式図. 右方への移動によりポテンシャルエネル ギーが減少する場合を示している

部分から流出すれば，その位置に欠陥が形成されること になる. 図 9 は, ジャンプ前後における系のポテンシャ ルエネルギーの変化 $\Delta E$ に着目したモンテカルロ法に よって, 表面と粒界の会合部近傍の原子移動をシミュレ 一トした結果である。 ポテンシャルを用い, 二次元六方格子 (アルミニウム (111) 面の平衡位置) の粒界 $(\Sigma 7)$ と表面の会合点近傍の 原子移動を温度 $473 \mathrm{~K}\left(200^{\circ} \mathrm{C}\right)$ の下で, 図 (a) 太線枠内 の原子を以下の手順で原子を移動させた.

移動手順任意の原子を抽出し, 隣接格子位置への ジャンプを試行する，試行した格子点にすでに原子が存 在しない場合は, 次の基準によりジャンプを決定する. 基準に適合しない場合は原子を元の位置に戻す. 全原子 についてこの手順を繰返す.

基準＼cjkstart試行により系のポテンシャルエネルギーが減 少する場合はすべて, 試行によりポテンシャルエネルギ が上昇する場合は確率 $\exp (-\Delta E / k T)$ に従ってその試 行を受入れる。

図 9 では, 左側面を表面として左端の各原子は左方へ のジャンプが可能であるが, 右端および上下端の原子は 不動である. 図より, 不安定な粒界と表面の会合部分か ら原子が移動して, 粒界に沿った凹部（粒界溝）が形成 される様子がわかる．表面と粒界の会合部では欠陥（粒 界溝）の初成が直ちに生じることから, 表面の存在に よってクリープキャビティよりも初成が著しく加速され る. 微小要素では久陥発生寿命が破損寿命に占める割合 が相対的に大きく，かつ，体積に比して表面積の割合が

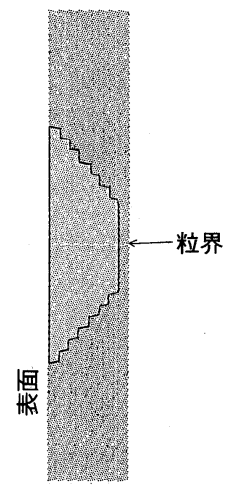

(a) 初期原子配置

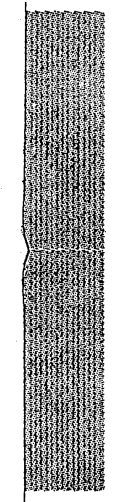

(b) $10^{5}$ ステップ

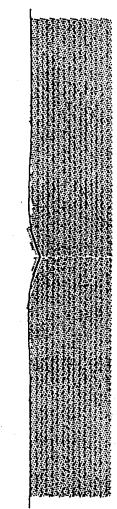

(c) $10^{6}$ ステップ

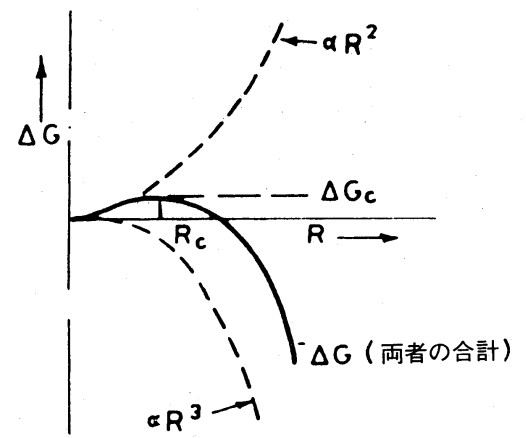

図10 部材内部の粒界上に発生するキャビティの半径 $R$ と系のポテンシャルエネルギーの変化 $\Delta G$ の 関係 ${ }^{26)}$. この場合は, 球形キャビティを仮定して, $R^{2}$ に比例する表面エネルギー増大と $R^{3}$ に比例す るクリープ変形によるエネルギー解放より, 系の エネルギー変化を算出

大きいため, 表面や粒界の会合部分の安定性評価が重要 であることがわかる.

一方, 部材内部の粒界上に発生するクリープキャビ ティの場合は, 図10に示すように, ある寸法 $R_{c}$ に達す るまではポテンシャルが増大し, 半径が $R_{c}$ を越えると 隇少に転ずるといわれている。 これは, 部材内部の粒界 上では半径 $R_{c}$ 以下のキャビティは消滅することを意味 している. したがって，粒界すべり等による粒界析出物 と母層の大規模なはく離等によって $R_{c}$ を越えるキャビ ティが生成（核生成）された場合のみ成長できる。この 核生成過程の解明にも原子シミュレーションは威力を発 揮するものと期待されるが，現時点では検討されていな い.

なお，原子シミュレーションの工学的な適用を考えた 場合, このような各原子の挙動の大略を簡単に解析でき る方法の開発が今後一層重要性を増すものと考えられる。

\section{4 欠陥成長の数值シミュレーション}

\section{$4 \cdot 1$ 表面拡散と粒界拡散}

拡散によるマクロなクリープ変形やキャビティ等の欠 陥の成長をシミュレーションするためには, さらに大量 の原子の移動を取扱う必要がある。いかに簡便な方法と いえどもこのような天文学的な数の原子移動を個々に取 扱うことは非効率的であるばかりではなく，仮に実施し

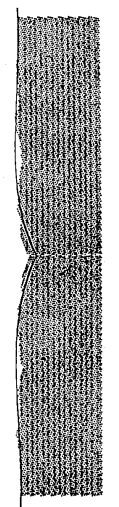

(d) $10^{7}$ ステップ

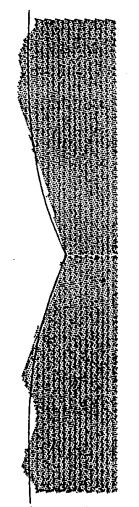

(e) $10^{8}$ ステップ

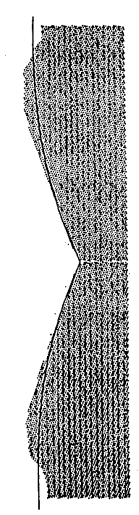

(f) $2 \times 10^{8}$ ステップ

図 9 モンテカルロ法による粒界溝初成シミュレーション25). 左端が表面であり, 中央部に $\sum 7$ 粒界を 導入している. 各点が 1 個の原子であり，原子移動は図(a)の太線枠内の原子を対象に行っている 
たとしても全体的な現象を見失う恐れがある。このよう な場合には，原子を集団として取扱う拡散方程式に基づ いた連続体力学的解析を行うのが合理的である.

固体表面の拡散による原子の流束 $J_{s}$ は，次式のよう に表面に沿った化学ポテンシャル $\mu$ の勾配に支配され る.

$$
J_{s}=-\left(D_{s} \delta_{s} / \Omega k T\right) \cdot \partial \mu / \partial s
$$

ここで， $D_{s}$ は表面拡散係数， $\delta_{s}$ は表面拡散層の厚さ， $\Omega$ は原子容積, $k$ はボルッマン定数, $T$ は温度, $s$ は 表面に沿った距離である. 表面の化学ポテンシャルは, 表面形状に依存し，

$$
\mu=\mu_{0}-\Omega \gamma_{s} \kappa
$$

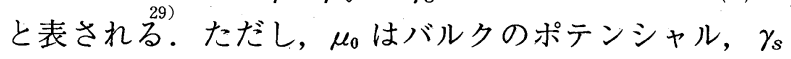
は表面エネルギ， $x$ は表面の曲率である，また，質量保 存則と組合わせると, 各表面の垂直方向相対変形速度 $V_{n}$ は

$$
V_{n}=-\left(D_{s} \delta_{s} / \Omega k T\right) \cdot \partial^{2} x / \partial s^{2}
$$

\section{と与えられる。}

一方，粒界に沿った原子の拡散は，

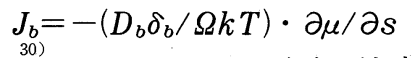

に支配される。 ここで， $J_{b}$ は原子の流束， $D_{b}$ は粒界拡 散係数， $\delta_{b}$ は粒界厚さである. 化学ポテンシャル $\mu$ は 垂直応力 $\sigma$ に依存し, 次式のように表される。

$$
\mu=\mu_{0}-\Omega \sigma
$$

質量保存則を考合わせると次式が得られる.

$$
\left(D_{b} \delta_{b} \Omega / k T\right) \partial^{2} \sigma / \partial s^{2}+\dot{\delta}=0
$$

ここで, $\dot{\delta}$ は粒界への原子の堆積速度である.

また，粒界と表面の会合点では表面は図11に示すよ うな

$$
2 \gamma_{s} \cdot \cos \psi=\gamma_{b}
$$

を満たす平衡角 $\psi$ を形成する。 なお， $\gamma_{b}$ は粒界エネル ギーである.

\section{$4 \cdot 2$ クリープキャビティの成長}

キャビティの成長機構を模式的に図 12 に示す. キャ ビティからの原子の流出（すなわち，キャビティ体積の 增大）は式(5)に律速される. キャビティ端の形状は式 (8) で規定されるが，キャビティ内では式 (2) に従って キャビティ形状を調整する原子の移動が起こる. キャビ テイ端からの原子流出速度（粒界拡散）に比べて形状の 調整速度（表面拡散）が充分速い場合には，キャビティ の曲率はほぼ一定となる（擬平衡状キャビティ）。逆に, 前者が速い場合には，形状が調整される前にキャビティ

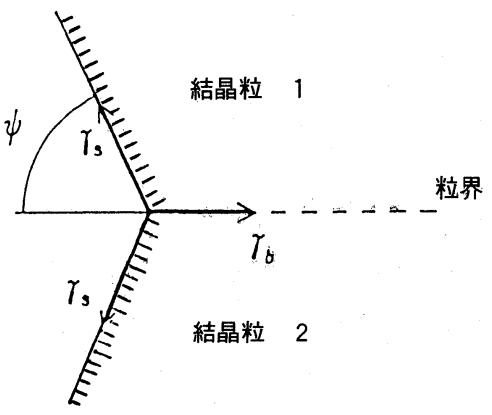

図11 表面と粒界の会合部における表面の平衡角 $\psi$
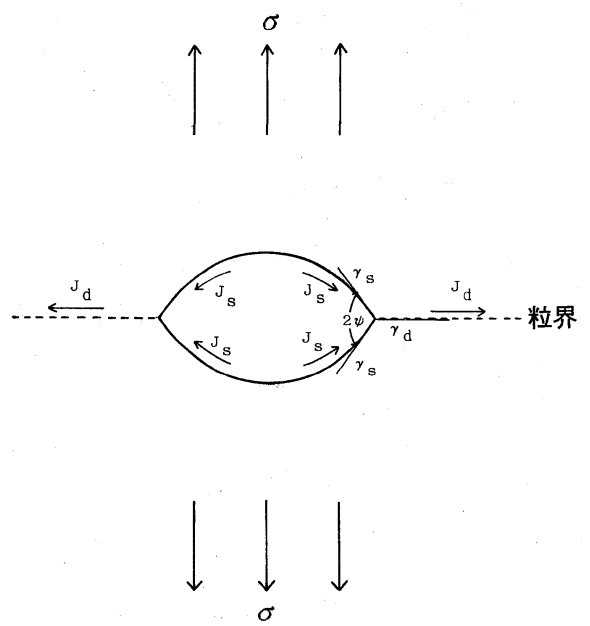

図12 クリープキャビティの成長機構を示す模式図. 粒界拡散 $J_{b}$ によりキャビティから原子が流出し, 表面拡散 $J_{s}$ によりキャビティ形状が变化する

端より原子が流出するため, 粒界に沿ったき裂状キャビ ティが形成される.

図13 は，遠方において一様な垂直応力を負荷された 粒界上に周期的にキャビティがある場合のシミュレー ション結果の一例である。 この場合, 粒界上の定常垂 直応力分布は式 (6), (7) より解析的に求められるため, 原子の流出速度が算出できる. 図13 は，キャビティ表 面を離散化して, 式 (8)の境界条件の下で式 (2) を差分法 により解くことにより求めたキャビティ形状の変化で ある。. また，図14 はキャビティの粒界上の半長 $a$ とそ の変化速度の関係である. ただし, 適当な無次元化を施 して表示している. キャビティが小さい時には球形に近 い擬平衡状であるが成長とともにき裂状に移行する．擬 平衡状では成長とともに速度がやや低下傾向を示すが, き裂状に移行するにしたがって加速される.

クリープキャビティの成長については多くの影響因子 があり, 数多くの解析的な研究が行われている.とりわ け，成長に複雑な影響を及ほす粒内クリープ変形，発生 時間・位置の不規則性，粒界ネットワー年等については, 数值シミュレーションを用いた検討が大きな威力を発揮 することが報告されている.
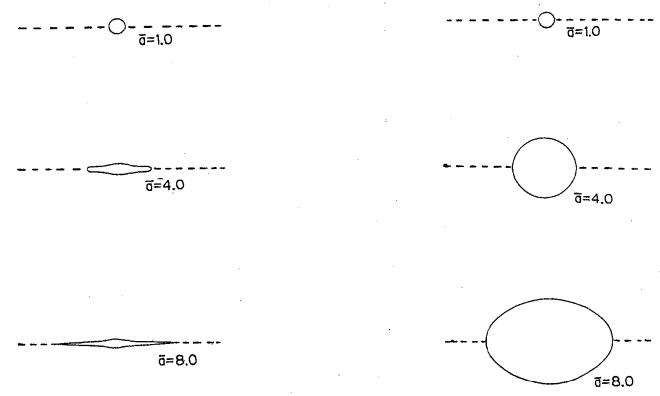

粒界

(a) $F=10^{4}$

(b) $F=0.01$

図13クリープキャビティの成長に伴う形状変化 ${ }^{32}$. ただし， $F=D_{b} \delta_{b} / D_{c} \delta_{c}$ (粒界拡散と表面拡散の 比） $\bar{a}$ は無次元化キャビティ半径, $\bar{\sigma}=4.5$ (無次 元化応力), $\bar{W}=10$ (無次元化ギャビティ間隔半 長) 


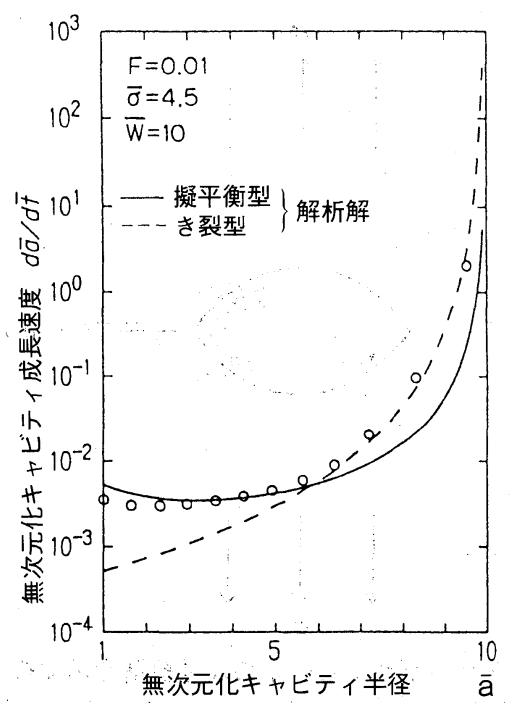

図14クリープキャビティの成長速度とキャビティ 半径の関係 ${ }^{32}$. 図中の実線と破線は，おのお の擬平衡状とき裂状の場合の解析解 31 を示す. ただし， $\bar{\sigma}=4.5$ (無次元化応力), $\bar{W}=10$ (無 次元化粒界長さ)

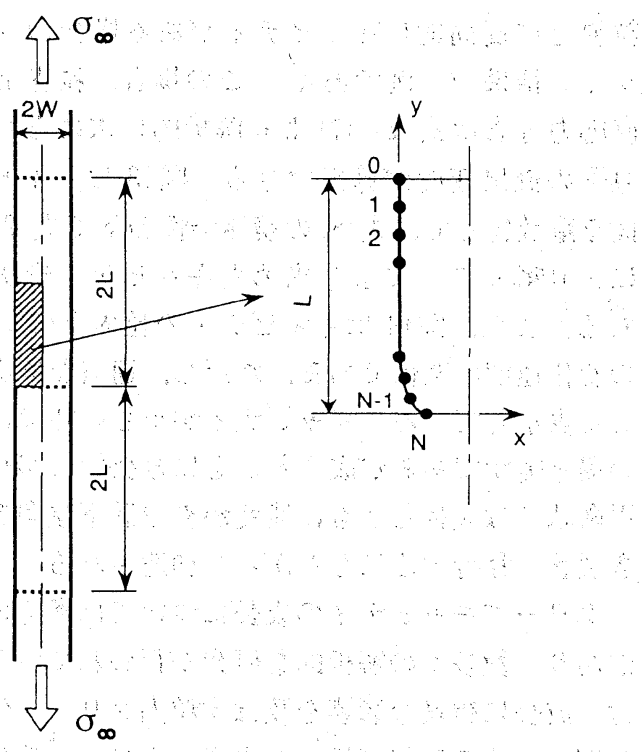

(a) Bamboo 構造を有する配線のモデル化

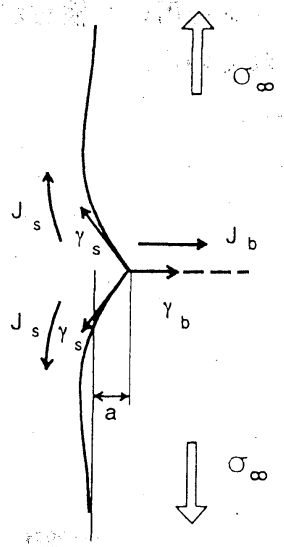

（b）表面と粒界の会合部近傍の原子の流れ

図15: 電子パッケージ内アルミニウム配線のスト レスマイグレーション破壊解析の説明図 ${ }^{40)}$

$4 \cdot 3$ 電子配線のストレス・マイグレーション破断 電子パッケージ内のアルミニウム配線においては, 電
子の流れによって配線原子が移動して欠陥が形成される エレクトロ・マイグレーション破断と熱応力の寄与に よって原子が移動して粒界に欠陥が形成されるストレス ・マイグレーション破断が, 信頼性確保の観点から大き な問題となっている.ここでは，後者の破損過程のシ ミュレーションについて紹介する.

図15 (a) は，電子パッケージ内の Bamboo 構造を有す るアルミニウム配線を模式的に示したものであり，粒界 は配線をほぼ垂直に横断している，解析は，粒界が周期 的に配線を横断し, 軸方向に引張り応力 $\sigma$ 絮荷され た二次元配線を対象とした，図15(b)に示すような表面 と粒界（破線）の会合点近傍においては，表面拡散によ る原子の流れ $J_{s}$ が誘起され，粒界に沿って開口の大き 以溝が発生する。.これは， 3 章の粒界溝初成シミュレ一 ション結果と対応している。この無応力下の粒界溝成長 は, 式(2)の表面拡散に関する拡散方程式を式(8)の境界 条件のもとで解いて解析的に求められる。 それによると, 溝深さ $a$ の時間に対する変化は,

$$
a=0.7803 \cdot \tan (\pi / 2-\psi)\left(D_{s} \delta_{s} \Omega \gamma_{s} t / k T\right)^{1 / 4}
$$

となる.ここで， $t$ は高温にさらされた時間であり， $a$ は初期表面位置より測定した溝深さである。図16 中の 破線は式(9)より求められた溝成長速度 $d a / d t$ と溝深 さの関係を示している。ただし，本解析では適当な無次 元化を行って示している. 溝は初期にはかなり高速で成 長するが，成長とともに急速に減速される。したがって， かなり微小な要素といえども無応力下では強度的な問題 となることはない.

一方，粒界に垂直な方向に引張り応力が作用する場合 には，粒界拡散によって溝先端から原子が粒界方向に流 出する（図15 (b)）の $J_{b}$ ) のため, 成長が加速される.

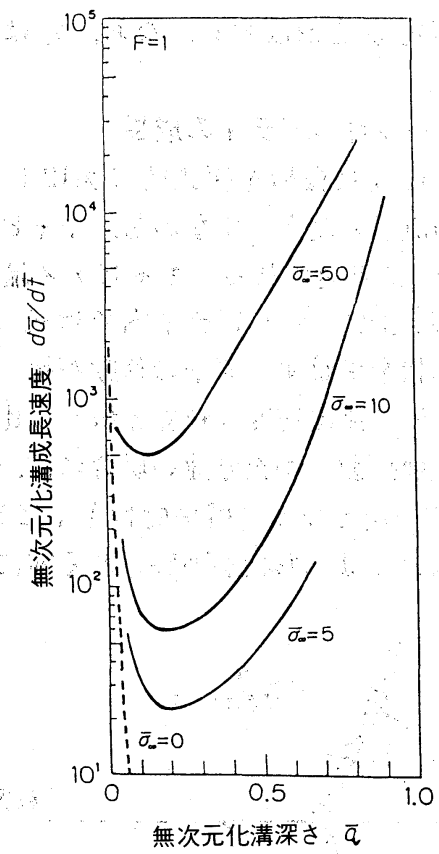

図16配線内を成長する粒界溝の成長速度と溝深さの 関係 ${ }^{40)}$. 破線は無応力状態に打ける解析解 ${ }^{41)}$. ただし， $F$ は粒界拡散と表面拡散の比， $\bar{\sigma}_{\infty}$ は無 次元化応力, $\bar{a}$ は無次元化溝深さ, $E$ は無次元 化時間である 
この場合には溝成長は解析的には解けないが, 前項のク リープキャビティの数值解析に用いた方法を適用するこ とができる，図16 中の実線は，差分法による計算より 得られた粒界溝の成長速度である.ごく初期を除くと成 長速度は応力に強く依存している. 初期の成長挙動は応 力にかかわらず破線と一致する傾向があり，溝発生およ び初期成長は表面拡散に支配されている。粒界溝は, 初 期にはいったん減速を示すものの，中期より再加速され る. 末期に著しく加速されるのは，“本計算では簡単のた め負荷荷重一定として計算しているので, 正味応力が増 大したためである. 実際の配線の熱応力は, 成長ととも に緩和されるため，末期の加速はさほど大きくないもの と考えられる。また：シミュレーションより得られた溝 形状変化より，表面拡散に比べて粒界拡散が活発である 場合（高応力，高 $F$ 值 $\left.\left(F=D_{b} \delta_{b} / D_{s} \delta_{s}\right)\right)$ には，粒界と 表面の会合点近傍原子は粒界に吸収されるため，粒界溝 は粒界に沿ったき裂状の形になる。一方，表面拡散が活 発である場合には (低応力, 低 $F$ 值), 開口の大きな粒 界溝が形成される、ストレス・マイグレーション破損配 線の観察より，条件によってき裂状および $\mathrm{V}$ 形の溝が

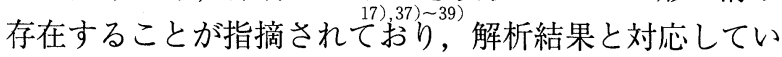
る.なお，実際の破損を厳密にシミュレーションする場 合には, 三次元解析とするのはもちろん, 応力状態や表 面や粒界の方位等，モデルの細部について考慮する必要 がある。

以上のような連続体力学解析で重要となるのは, 拡散 定数, 表面エネルギー, 界面エネルギー等の材料定数の 值である．特に，局所における值が局所破損を支配する ことになるが，多様な局所応力条件下においてさまざま な表面や粒界に対する值を実験的に正確に求めることは 非常に困難である．2章に述べた分子動力学法やメトロ ポリス法による評価が大きな威力を発揮すると期待でき る.

\section{5 おわりに}

本稿では高温問題を中心としたが，高温に限らず破壊 問題に原子シミュレーションが適用されてきている。し かし，これらは，現時点では十分に成熟した分野とは言 い難く，今後に残されている問題が大半と言わざるをえ ない. 本文の中でも高温強度に関連していくつかの将来 の方向性について言及したが，触れなかった点の中で最 も大切なものは，異種原子間の特性に関するものである. すでに，合金や粒界偏析についての研究報告があるが, 破壊過程の解明という点では体系的な検討は皆無といえ る. また, 複合材料や微小機器（電子部材やマイクロマ シン）要素の強度や信頼性について考える時, 異種材料 間の界面破壊を原子オーダより解明することが今後に残 されたさらに大きな課題である。このためには, 異種原 子間の適切なポテンシャルの開発が重要となろう.

また，本稿では第一原理手法についても触れなかった が, 表面や界面の構造が解析されている. 第一原理手法 には膨大な計算を要するが，破壊には一般に多くの原子 が関与することから，直接破壊をシミュレーションする
手段としては適当ではないと思われる. しかし，効率的 な第一原理手法の開発や，原子間ポテンシャルを第一原 理手法の計算結果を用いて定式化して合理的かつ効率的 なシミュレーション方法を探ることによって破壊研究の 基盤強化に寄与すると考えられる，構成式等における材 料定数を実験的・経験的に求める従来の力学とは異なり, 非経験的にシミュレーションを行える点は大きな魅力で あり, 現象の素過程の解明やシミュレーションの妥当性 の検証のため長期的な視点に立った検討が必要年なうう.

本稿をまとめるにあたり, 京都大学工学部 大谷隆一 教授には懇切なご助言およびご援助をいただいた。 心よ り謝意を表します。

\section{参 考 文 献}

1 ) A. S. Tetelman and A. J. McEvily, Jr. 著, 宮本，博訳, “構造材料の強度と破壊”, p. 36 (1970) 培風館

2 ）森田清三, “走査型プローブ顕微鏡のすべて”.(1992) 工業 調査会

3 ) 堂山昌男, 山本良一, “計算物理学と計算化学” 3 章, 田 中 実, 山本良一編, p. 43（1988）海文堂

4 ) 田中 実, 文献 3) の 1 章, p. 1 (1988).

5 ) 岡田 勲, 三上益弘, “分子シミュレーション入門” 3 章, 岡田 勲, 大沢映二編, p. 37 (1989) 海文堂

6) 上田 顕, “コンピュータシミュレーション”, p. 10; p. 75 （1990）朝倉書店

7 ) 岡崎 進, 文献 5) の 4 章, p. 63 (1989)

8 ) R. J. Harrison, G. A. Bruggeman and G. H. Bishop, Grain Boundary Structures and Properties, Ed. by G. A. Chadwick and D. A. Smith, Academic Press, p. 45 (1976).

9 ) D. Wolf and K. L. Merkle, Materials Interfaces, Cap. 3, Ed. by D. Wolf and S. Yip, Chapman \& Hall, p. 87 (1992).

10) G. Hasson and C. Goux, Scr. Met., 5, 889 (1971).

11）大谷隆一, 北村隆行, 尾代如月, 未発表デー夕

12) L. E. Murr, G. I. Wong and R. J. Horylev, Acta Met., 21, 595 (1973).

13) L. E. Murr, Interfacial Phenomena in Metals and Alloys, Addison-Wesley Publishing Company, p. 130 (1975).

14) S. M. Foils, M. I. Baskes and M. S. Daw, Physical Review B, 33, 7983 (1986).

15) M. Hasunuma, H. Kaneko, A. Sawabe, T. Kawanoue, Y. Kohanawa, Y. Komatsu and M. Miyauchi, International Electron Device Meeting, Technical Digest, IEEE, p. 677 (1989).

16）屋代如月, 北村隆行, 大谷隆一, 日本機械学会講演論文集, No. 944-1, p. 245 (1994). 北村隆行, 大谷隆一, 屋代如 月, 日本材料学会第43期学術講演会前刷 (1994).

17) 岡林秀和, 応用物理, 59, 1461 (1990).

18) T. Kwok, P. S. Ho and S. Yip, Physical Review B, 29, 5354 (1984).

19) T. Kwok, P. S. Ho and S. Yip, Physical Review B, 29, 5363 (1984).

20）北川 浩, 渋谷陽二, 中谷彰宏, 斉藤賢一, 日本機械学会 講演論文集, No. 944-1, p. 242 (1994).

21) G. H. Bishop, R. J. Harrison, T. Kwok and S. Yip, J. Appl. Phys., 53, 5609 (1982) 
22）岩崎富生, 佐々木直哉, 千葉矩正, 阿部康夫, 日本機械学 会講演論文集, No. 930-71, p. 189 (1993).

23) S. R. Phillpot, S. Yip, P. R. Okamoto and D. Wolf, 文献 (9) の Chap. 7, p. 228 (1990).

24) Monte Carlo Method in Statistical Physics, Ed. by K. Binder, Springer-Verlag (1986).

25）北村隆行, 大谷隆一, 山中哲哉, 屋代如月, 日本機械学会 論文集 A 編，掲載予定.

26) H. E. Evans, Mechanisms of Creep Fracture, Elsevier Applied Science Publishers, p. 43 (1984).

27）北村隆行，日本機械学会誌，Vol. 97, p. 646 (1994).

28） P. G. Shewmon 著, 笛木和雄, 北沢宏一共訳, “固体内の 拡散”, p. 183 (1976) コロナ社

29) C. Herring, J. Appl. Phys., 21, 437 (1950).

30) D. Hull and D. E. Rimmer, Phil. Mag., 4, 673 (1954).

31) T. J. Chuang, K. I. Kagawa, J. R. Rice and L. B. Sills, Acta Met., 27, 265 (1979).

32）山中哲哉, 北村隆行, 大谷隆一, 見平吉範, 日本材料学会 第41期学術講演会前刷，p. 43 (1992).

33) L. Martinez and W. D. Nix, Met. Trans. A, 12A, 23 (1981).
34) A. Needleman and J. R. Rice, Acta Met., 28, 1315 (1980).

35) S. J. Fariborz, D. G. Harlow and T. J. Delph, Acta Met., 34, 1433 (1986).

36）北村隆行，大谷隆一，山中哲哉，服部芳明，日本機械学会 論文集，A-60，935 (1994).

37）安食恒雄監修, “半導体デバイスの信頼性技術”, p. 192 （1988）日科技連

38）日野出憲治，軽金属，41，614（1991）.

39）日野出憲治，日本金属学会会報，28，41（1989）.

40) T. Kitamura, R. Ohtani and T. Yamanaka, JSME International Journal, Ser. A, 36, 146 (1993).

41) W. W. Mullins, J. Appl. Phys., 28, 333 (1957).

42) S. M. Foiles and M. S. Daw, J. Mater. Res., 2, 5 (1987).

43) Y. Ishida, M. Mori and M. Hashimoto, Surface Science, 144, 253 (1984).

44）塚田 捷, “表面物理入門”, p. 11 （1989）東京大学出版 会

45) R. Car and M. Parrinello, Physical Review Letters, 55, 2471 (1985).

46）北川 浩, 渋谷陽二, 尾方成信, 日本機械学会講演論文集, No. 944-1, p. 237 (1994). 